\title{
The General Isothermal Oxidation Behavior of $\mathrm{Cu}-8 \mathrm{Cr}-4 \mathrm{Nb}$
}

L.U.J.T. Ogbuji

QSS, Inc., NASA Glenn Research Center, Cleveland OH 44135

\begin{abstract}
Oxidation kinetics of $\mathrm{Cu}-8 \mathrm{Cr}-4 \mathrm{Nb}$ was investigated by TGA exposures between 500 and $900^{\circ} \mathrm{C}$ (at $25-50^{\circ} \mathrm{C}$ intervals) and the oxide scale morphologies examined by microscopy and micro-analysis. Because $\mathrm{Cu}-8 \mathrm{Cr}-4 \mathrm{Nb}$ is comprised of fine $\mathrm{Cr}_{2} \mathrm{Nb}$ precipitates in a $\mathrm{Cu}$ matrix, the results were interpreted by comparison with the behavior of copper (OFHC) and "NARloy-Z" (a rival candidate material for thrust cell liner applications in advanced rocket engines) under the same conditions. While NARloy- $\mathrm{Z}$ and $\mathrm{Cu}$ exhibited identical oxidation behavior, $\mathrm{Cu}-8 \mathrm{Cr}-4 \mathrm{Nb}$ differed markedly in several respects: below $\sim 700^{\circ} \mathrm{C}$ its oxidation rates were significantly lower than those of $\mathrm{Cu}$; At higher temperatures its oxidation rates fell into two categories: an initial rate exceeding that of $\mathrm{Cu}$, and a terminal rate comparable to that of $\mathrm{Cu}$. Differences in oxide morphologies paralleled the kinetic differences at higher temperature: While NARloy- $\mathrm{Z}$ and $\mathrm{Cu}$ produced a uniform oxide scale of $\mathrm{Cu}_{2} \mathrm{O}$ inner layer and $\mathrm{CuO}$ outer layer, the inner $\left(\mathrm{Cu}_{2} \mathrm{O}\right)$ layer on $\mathrm{Cu}-8 \mathrm{Cr}-4 \mathrm{Nb}$ was stratified, with a highly porous/spongy inner stratum (responsible for the fast initial kinetics) and a dense/blocky outer stratum (corresponding to the slow terminal kinetics). Single and spinel oxides of $\mathrm{Nb}$ and $\mathrm{Cr}$ were found at the interface between the oxide scale and $\mathrm{Cu}-8 \mathrm{Cr}-4 \mathrm{Nb}$ substrate and it appears that these oxides were responsible for its suppressed oxidation rates at the intermediate temperatures. No difference was found between $\mathrm{Cu}-8 \mathrm{Cr}-4 \mathrm{Nb}$ oxidation in air and in oxygen at $1.0 \mathrm{~atm}$.
\end{abstract}

\section{Introduction}

The combustion chambers in hypersonic engines are subject to severe mechanical and thermal loads and must be lined with materials of high thermal conductivity and excellent high-temperature mechanical properties. Copper alloys are best suited to that application, and the main combustion chamber of the space shuttle is lined with a $\mathrm{Cu}-\mathrm{Ag}-\mathrm{Zr}$ alloy designated "NARloy-Z", a solution-strengthened alloy with 3 wt. \% Ag and 0.5 wt \% Zr in $\mathrm{Cu}$. For future reusable launch vehicles a leading candidate for thrust-cell liner is a $\mathrm{Cu}$ 8Cr-4Nb alloy designated "GRCop-84" (for NASA Glenn Research Center, where it was developed in conjunction with neighboring Case Western Reserve University). This alloy is a fine dispersion of 14 vol. $\% \mathrm{Cr}_{2} \mathrm{Nb}$ in $\mathrm{Cu}$, and is characterized by markedly improved mechanical properties without significant reduction of thermal conductivity [1].

Oxidation is always an issue in engine applications, and especially so in these alloys. The $\mathrm{Cu}$ matrix of $\mathrm{Cu}-8 \mathrm{Cr}-4 \mathrm{Nb}$ has poor oxidation resistance, while the chromium content is publication. Because of changes that may be made before formal publication, this preprint is made available with the understanding that it will not be cited or reproduced without the permission of the author. 
both inadequate for $\mathrm{Cr}_{2} \mathrm{O}_{3}$ protection. Copper and its alloys are known to undergo an oxidation-related damage known as 'blanching', in which cycles of oxidation-reduction produce localized ratcheting degradation resulting in hot spots, pores, and cracks. Rocket engines and combustors lined with $\mathrm{Cu}$ alloys and fuelled with $\mathrm{H}_{2}-\mathrm{O}_{2}$ mixtures present near-ideal conditions for blanching occurrence. While blanching requires a localized fluctuation of thermodynamic conditions [2], its inception lies in oxidation; hence it is important to understand the oxidation behavior of $\mathrm{Cu}-8 \mathrm{Cr}-4 \mathrm{Nb}$ and related materials.

Copper is of great importance in various industries, and its oxidation behavior has been the subject of many studies. A review by Ronnquist and Fischmeister [3], categorized the wide spectrum of oxidation behavior exhibited by $\mathrm{Cu}$ under various conditions. Park and Natesan [4] mapped out $\mathrm{Cu}$ oxidation kinetics in three temperature regimes, concluding that surface transport was dominant at low temperatures (below $\sim 500^{\circ} \mathrm{C}$ ), grain boundary diffusion at intermediate temperatures, and bulk diffusion above $\sim 700^{\circ} \mathrm{C}$. Whereas it used to be merely assumed, largely from consideration of activation energies, that diffusion of copper ions to the oxide surface was rate determining $[3,4]$, more direct evidence for that mechanism is now available from observed effects of externally applied electric charges on scale growth kinetics $[5,6]$. The $\mathrm{Cu}-\mathrm{Cr}-\mathrm{Nb}$ composition field is less well understood.

Chiang and co-workers have evaluated the oxidation resistance of $\mathrm{Cu}-\mathrm{Nb}$ and $\mathrm{Cu}-\mathrm{Cr}$ coatings proposed for rocket engine applications [7-9]. Using minicomposites made by co-deposition of the elemental constituents from vapor phase or by sputtering, they found that: (1) $\mathrm{Cu}-\mathrm{Nb}$ formed a non-protective duplex scale, with the thickening of $\mathrm{CuO} / \mathrm{Cu}_{2} \mathrm{O}$ at the surface controlled by outward diffusion of $\mathrm{Cu}$, while inward diffusion of oxygen controlled the growth of a poorly consolidated subscale comprised of niobium oxides $\left(\mathrm{Nb}_{2} \mathrm{O}_{5}\right.$ and $\left.\mathrm{CuNb}_{2} \mathrm{O}_{6}\right)$; (2) in $\mathrm{Cu}-\mathrm{Cr}$ a Cr content of 15 - 30 vol \% was necessary to assure formation of a continuous and protective $\mathrm{Cr}_{2} \mathrm{O}_{3}$ top scale.

In a study of $\mathrm{Cu}-8 \mathrm{Cr}-4 \mathrm{Nb}$ oxidation in air from 482 to $816^{\circ} \mathrm{C}$, Chiang and Grimmett found two regimes of different activation energies. Parabolic rate constants for oxidation of $\mathrm{Cu}-8 \mathrm{Cr}-4 \mathrm{Nb}$ were found to be slower than those for $\mathrm{Cu}$ between $482{ }^{\circ} \mathrm{C}$ and $816^{\circ} \mathrm{C}$, 
the rate constants $\left(\mathrm{k}_{\mathrm{p}}\right.$, in $\left.\mathrm{gm}^{2} / \mathrm{cm}^{4} \mathrm{~h}\right)$ differing by two orders of magnitude at $\sim 650^{\circ} \mathrm{C}$; however, the oxidation rates of the two materials converged at the high and low ends of that temperature interval [10]. That is an interesting result because the oxidation behavior of other $\mathrm{Cr}_{2} \mathrm{Nb}$-containing alloys [11] and of $\mathrm{Cu}-\mathrm{Cr}$ and $\mathrm{Cu}-\mathrm{Nb}$ [7-9] give no indication that the $\mathrm{Cr}_{2} \mathrm{Nb}$ precipitates in $\mathrm{Cu}-8 \mathrm{Cr}-4 \mathrm{Nb}$ might confer any oxidative advantage. In any case, even the complete oxidation of the 8 at $\% \mathrm{Cr}$ in this alloy would be insufficient to provide complete $\mathrm{Cr}_{2} \mathrm{O}_{3}$ coverage. Yet the results of Chiang and Grimmett indicate that something else is going on besides oxidation of the $\mathrm{Cu}$ matrix. Hence, the reason for the oxidative superiority of $\mathrm{Cu}-8 \mathrm{Cr}-4 \mathrm{Nb}$ remains unclear; and the aim of this paper is to examine its oxidation behavior vis-à-vis that of NARloy- $\mathrm{Z}$ and, especially, pure $\mathrm{Cu}$.

\section{Procedure}

The materials examined in this study were: $\mathrm{Cu}-8 \mathrm{Cr}-4 \mathrm{Nb}$ bars containing a slight excess of $\mathrm{Cr}$ (with a $\mathrm{Cr} / \mathrm{Nb}$ atomic ratio of 2.05 to prevent hydride formation by ensuring all $\mathrm{Nb}$ is tied up as $\mathrm{Cr}_{2} \mathrm{Nb}$ ), NARloy-Z bars, and $\mathrm{Cu}$ bars obtained as commercial OFHC-Cu. Test specimens were cut into disks $20 \mathrm{~mm}$ in diameter and $1.0 \mathrm{~mm}$ thick, with a $3 \mathrm{~mm}$ hole near the rim for hanging, and polished to 800-grit final smoothness. Oxidation was performed in a thermogravimetric analyzer (TGA), the coupons hanging from a sapphire wire inside the $25 \mathrm{~mm}$-diameter inner quartz tube of the TGA. The oxidant was purified and dried oxygen (and in some cases air) at $1.0 \mathrm{~atm}$. flowing at $100 \mathrm{~cm}^{3} /$ minute.

Oxidation temperatures were $50^{\circ} \mathrm{C}$ apart from 500 to $650^{\circ} \mathrm{C}$ and above $850^{\circ} \mathrm{C}$, but the intervals were narrowed to $25^{\circ} \mathrm{C}$ for $\mathrm{Cu}-8 \mathrm{Cr}-4 \mathrm{Nb}$ in the temperature regimes $\left(700-850^{\circ} \mathrm{C}\right)$ where the kinetics were found to be most sensitive to temperature. Weight changes were acquired continuously by a Cahn 1000 electrobalance with a $100 \mu \mathrm{g}$ sensitivity. Each test lasted $50 \mathrm{H}$, a much longer duration than the expected service lifetimes of rocket liners. The long duration was chosen in an effort to grow oxide scales that could be handled and studied; trials for shorter times $(0.5,1.0,2.0,5.0,10$, and $20 \mathrm{H})$ yielded oxides that flaked off and curled up upon removal of the sample. Cohesion of the oxide scale improved with longer oxidation duration. 
Oxidized samples were sectioned and examined by standard metallographic techniques, including XRD, SEM and EDS. Rigorous analyses of the TGA data for significant changes in parabolic oxidation rate constant, $\mathrm{k}_{\mathrm{p}}$, were performed by Real World Quality Systems of Rocky River, Ohio.

\section{Results and Discussion}

\section{Oxidation Kinetics}

Copper is an important reference material in this study, and accurate reproduction of literature results for its oxidation will lend fidelity to comparisons made in this paper. Fig. 1 is an Arrhenius plot of data obtained for $\mathrm{Cu}$ oxidation kinetics in oxygen. Two regimes are evident: one at high temperatures with an activation energy of $150 \mathrm{~kJ} / \mathrm{mol}$ $(1.55 \mathrm{eV})$, and another at lower temperatures with an activation energy of $\sim 85 \mathrm{~kJ} / \mathrm{mol}$ $(0.88 \mathrm{eV})$. This is in very good agreement with the results of Park and Natesan [4], who reported activation energies of $1.79 \mathrm{eV}$ and $0.87 \mathrm{eV}$, respectively, for the two regimes. (They also found an activation energy of $2.32 \mathrm{eV}$ for a third regime, below $450^{\circ} \mathrm{C}$, which was not explored in this study.) The oxidation behavior of NARloy- $Z$ was just as simple. Fig. 2 is a parabolic plot of the data for oxidation of NARloy- $\mathrm{Z}$ and $\mathrm{Cu}$ in $\mathrm{O}_{2}$ at 600 and $800^{\circ} \mathrm{C}$. It is typical of the results obtained for these two materials at low and high temperatures, respectively. The two curves are coincident at the lower temperature and also almost identical at the higher temperature. Clearly, there is little difference in the oxidation kinetics of NARloy- $\mathrm{Z}$ and $\mathrm{Cu}$. In contrast, $\mathrm{Cu}-8 \mathrm{Cr}-4 \mathrm{Nb}$ oxidation exhibited much complexity.

Specific weight gain is plotted in Fig. 3 as a function of the square root of exposure time for $\mathrm{Cu}-8 \mathrm{Cr}-4 \mathrm{Nb}$ oxidation at three representative temperatures. (The classification of temperature regimes in this paper is in conformity with terminology in the literature: i.e. paralleling - but not necessarily coincident with - the regimes for $\mathrm{Cu}[3,4]$.) At the low temperatures (exemplified by $550^{\circ} \mathrm{C}$ in Fig. 3) the kinetics were found to be parabolic, while at higher temperatures they may be called "quasi-parabolic", with the following meaning: At intermediate temperatures $\left(700^{\circ} \mathrm{C}\right)$ the kinetics oscillated about a mean slope in a manner that is consistent with occasional oxide spallation during its growth; at high 
temperature $\left(850^{\circ} \mathrm{C}\right)$, in addition to the indication of dynamic spallation, the plots were best fitted as two separate kinetic regimes indicated by the superposed dotted lines. That the slopes of lines I and II are significantly different will be taken up below. Note, also, that while oscillation of the plots suggests some spallation during oxidation, the effect is not large enough to obscure the gross trends of weight gain. For instance, the plots do not flatten out to become sub-parabolic [12] or dip into the terminal weight-loss behavior commonly observed when oxide growth is diminished by concomitant oxide loss through significant spallation [13] or recession $[14,15]$. Therefore, for the purpose of discussing kinetics, $\mathrm{Cu}-8 \mathrm{Cr}-4 \mathrm{Nb}$ oxidation may be said to obey parabolic behavior, and Arrhenius plots may be used to analyze the kinetics.

Fig. 4 shows that the oxidation behavior of $\mathrm{Cu}-8 \mathrm{Cr}-4 \mathrm{Nb}$ was substantially the same in air and $\mathrm{O}_{2}$. Ignoring for now the splitting of $\mathrm{O}_{2}$ oxidation data into two branches at higher temperatures (top left), the significance of which will be discussed later, the results in $\mathrm{O}_{2}$ (diamonds) are practically coincident with those obtained in air (circles). Hence, allusions in this paper to $\mathrm{Cu}-8 \mathrm{Cr}-4 \mathrm{Nb}$ oxidation behavior in oxygen should be understood to apply to air also. Besides bifurcation, the $\mathrm{O}_{2}$ data in Fig. 4 exhibit substantial scatter. Still, as explained earlier, the overall trends are clear enough for meaningful determination of $\mathrm{k}_{\mathrm{p}}$ values. With these qualifications in mind, the oxidation behavior of $\mathrm{Cu}-8 \mathrm{Cr}-4 \mathrm{Nb}$ will now be compared with that of $\mathrm{Cu}$ and NARloy-Z.

A comparison is shown in Fig. 5, in which the $\mathrm{Cu}-8 \mathrm{Cr}-4 \mathrm{Nb}$ data for each temperature have been simplified by averaging. The point of interest in this figure is that, while the oxidation rates ( $\mathrm{k}_{\mathrm{p}}$ values) for NARloy- $\mathrm{Z}$ and $\mathrm{Cu}$ are coincident at all temperatures, those of $\mathrm{Cu}-8 \mathrm{Cr}-4 \mathrm{Nb}$ are slower at intermediate temperatures $\left(500 \sim 650^{\circ} \mathrm{C}\right)$ by an order of magnitude; above $\sim 700^{\circ} \mathrm{C}$ oxidation kinetics of all three materials converge. This agrees with the observation of Chiang and Grimmett [10]. In Fig. 6 the data for $\mathrm{Cu}-8 \mathrm{Cr}-4 \mathrm{Nb}$ oxidation are shown in full, revealing the complexity of its behavior. Below $\sim 700^{\circ} \mathrm{C}$, as noted, its parabolic rate constants are up to ten times lower than those for $\mathrm{Cu}$. The slope shown for $\mathrm{Cu}-8 \mathrm{Cr}-4 \mathrm{Nb}$ in this figure (calculated by regression with $\mathrm{R}^{2}=0.968$ ) indicates an activation energy of $\sim 98 \mathrm{~kJ} / \mathrm{mol}$, which is close to the $85 \mathrm{~kJ} / \mathrm{mol}$ for $\mathrm{Cu}$ in this regime. 
The behavior of $\mathrm{Cu}-8 \mathrm{Cr}-4 \mathrm{Nb}$ at high temperatures is characterized by the appearance of two kinetic branches. The lower branch represents oxidation rates similar to those of $\mathrm{Cu}$, while the upper branch represents rates 4-5 times faster than for $\mathrm{Cu}$. The two branches correspond to fast initial kinetics and slow terminal kinetics in $\mathrm{Cu}-8 \mathrm{Cr}-4 \mathrm{Nb}$ oxidation, as illustrated in Fig. 7 and Table 1 for $800^{\circ} \mathrm{C}$. The oxide microstructures in Fig. 7 correlate with the different kinetic zones, as indicated: 1 mage I is from the oxide region nearest to the substrate and represents early growth, its spongy morphology being evident in the higher-magnification image below; Image II is from the outermost region of the scale and represents the dense, final-stage oxide. Clearly, the initial stage oxide on $\mathrm{Cu}-8 \mathrm{Cr}-4 \mathrm{Nb}$ is poorly protective, but porosity diminished with progress of oxidation so that the terminalstage oxidation product was dense, blocky, and protective.

The validity of this interpretation (assigning two kinetic stages in Fig. 7) was checked by statistical analysis for the region $800-900^{\circ} \mathrm{C}$, at $25^{\circ} \mathrm{C}$ intervals. The result is summarized in Table 1. Column 2 gives the duration of Regime I, the fast initial stage of oxidation; the next column gives the duration of Regime II (terminal stage); and the next columns give Regimes I and II $k_{p}$ values, and their ratios. The $k_{p}$ values were determined by linear regression, one of the criteria of fit being an $\mathrm{R}^{2}$ value of 0.995 or better. In cases where multiple measurements were made, the average values are shown in parenthesis. The combined durations of Regimes I and II do not add up to 50 hours because the earliest oxidation stage and the time of transition from I to II were omitted. There seems to be a trend towards a lengthening of Regime II duration with increasing temperature (at the expense of Regime I) up to a point. Except for the highest temperatures $\left(875\right.$ and $900^{\circ} \mathrm{C}$ ) where Zone I is practically absent, the ratio $\mathrm{k}_{\mathrm{p}(\mathrm{I})} / \mathrm{k}_{\mathrm{p}(\mathrm{II})}$ is fairly constant.

\section{The Oxides}

At all temperatures the oxide was comprised mainly of a thick scale of $\mathrm{Cu}_{2} \mathrm{O}$, topped by a film of $\mathrm{CuO}$, the two layers being in the thickness ratio of 20:1 in most cases. Whiskers were observed on top of the $\mathrm{CuO}$ veneer, especially on oxides grown below $\sim 750^{\circ} \mathrm{C}$, the whisker profusion increasing at lower temperatures. For NARloy- $\mathrm{Z}$ and $\mathrm{Cu}$ both the $\mathrm{CuO}$ and $\mathrm{Cu}_{2} \mathrm{O}$ layers appeared to be comparably dense; but for $\mathrm{Cu}-8 \mathrm{Cr}-4 \mathrm{Nb}$ the inner oxide 
$\left(\mathrm{Cu}_{2} \mathrm{O}\right)$ always exhibited a porous inner region and a dense outer region, presumably giving rise to the two different oxidation rates described earlier.

Fig. 8 compares oxide scales that grew on the three materials at $800^{\circ} \mathrm{C}$. In each case the oxide-substrate boundary is to the right and marked with a block arrow; the gas interface is to the left. The total oxide thickness after 50 hours was $890 \mu \mathrm{m}$ on $\mathrm{Cu}-8 \mathrm{Cr}-4 \mathrm{Nb}, 520$ $\mu \mathrm{m}$ on NARloy- $\mathrm{Z}$, and $490 \mu \mathrm{m}$ on $\mathrm{Cu}$. $\mathrm{Cu}-8 \mathrm{Cr}-4 \mathrm{Nb}$ produced the least homogeneous oxide, followed by $\mathrm{Cu}$. In all $800^{\circ} \mathrm{C}$ oxides on $\mathrm{Cu}-8 \mathrm{Cr}-4 \mathrm{Nb}$ the inner (porous) region and outer (dense) region were found to be of about the same thickness. That lends further support to the correlation suggested earlier between the bifurcation of kinetics and oxide morphological changes. Oxide thickness, $\Delta \mathrm{x}$, is related to oxidation time through the parabolic rate constants $\mathrm{k}_{\mathrm{x}}$ as follows:

$$
(\Delta \mathrm{x})^{2}=\mathrm{A}+\mathrm{k}_{\mathrm{x}} \mathrm{t} .
$$

Omitting the constant term (which only corrects for a pre-existing oxide film) it becomes:

$$
(\Delta \mathrm{x})^{2}=\quad \mathrm{k}_{\mathrm{x}} \mathrm{t} .
$$

Since the oxide-thickening rate constant, $\mathrm{k}_{\mathrm{x}}$, is related to the weight-gain parabolic rate constant, $\mathrm{k}_{\mathrm{p}}$, by a mere scaling constant, $\alpha$, eq. 2 reduces to:

$$
(\Delta \mathrm{x})^{2}=\alpha \mathrm{k}_{\mathrm{p}} \mathrm{t}
$$

Hence, if suffix 1 applies to Regime I and 2 to Regime II, eqn. 3 yields:

$$
\frac{\left(\Delta x_{1}\right)^{2}}{\left(\Delta x_{2}\right)^{2}}=\left(\frac{k_{1}}{k_{2}}\right) \cdot\left(\frac{t_{1}}{t_{2}}\right)
$$

At $800^{\circ} \mathrm{C}$ the dense and porous oxide layers are of roughly equal thickness (Fig. 8), and one can write:

$$
\left(\frac{k_{1}}{k_{2}}\right)=\left(\frac{t_{2}}{t_{1}}\right)
$$


In Table $1 \mathrm{k}_{\mathrm{I}} / \mathrm{k}_{\mathrm{II}} \sim 2.8$ at $800^{\circ} \mathrm{C}$, while $\mathrm{t}_{\mathrm{II}}=30$ hours and $\mathrm{t}_{\mathrm{I}}=3$ hours, giving $\mathrm{t}_{\mathrm{II}} / \mathrm{t}_{\mathrm{I}} \sim 3.0-$ in agreement with eq (5).

The XRD results shown in Table 2 revealed single and mixed (spinel) oxides of $\mathrm{Cr}$ and $\mathrm{Nb}$ beneath the scale. X-ray scans of the oxide scale from the top detected only $\mathrm{CuO}$ and $\mathrm{Cu}_{2} \mathrm{O}$; but when the oxide scale was removed from the substrate, the diffraction peaks from the non- $\mathrm{Cu}$ oxides became strong enough for identification. Fig. 9 is the profile of a sample oxidized at $800^{\circ} \mathrm{C}$. The sample cross-section after removal of the main oxide overburden $\left(\mathrm{CuO}+\mathrm{Cu}_{2} \mathrm{O}\right)$ is shown in Fig. 9(a), and the EDS line scan along the dotted line is shown in Fig. 9(b). The Cu peaks were suppressed in 9(b) to fit them on the same vertical scale as the other elements. Both Figs. 9(a) and (b) reveal a film of secondary oxides ( $\mathrm{Cr}-\mathrm{Nb}$ oxides) hugging the contour of the substrate. The $\mathrm{Cu}$ profile in Fig. 9(b) exhibits minima at the surface $(\mathrm{Cr}-\mathrm{Nb}-\mathrm{O})$ layer and at points that coincide with $\mathrm{Cr}$ and $\mathrm{Nb}$ peaks from the $\mathrm{Cr}_{2} \mathrm{Nb}$ precipitates. Alongside the $\mathrm{Cr}-\mathrm{Nb}-\mathrm{O}$ layer is a denuded band a narrow strip that is devoid of precipitates. The configuration of secondary oxide film, matrix, and precipitates is accentuated in Fig. 10, which shows a higher-magnification image of the area with corresponding maps of $\mathrm{Cu}, \mathrm{Cr}$, and $\mathrm{Nb}$ distribution. It confirms that the secondary oxide layer has $\mathrm{Cr}$ and $\mathrm{Nb}$ (and $\mathrm{O}$ ) but no $\mathrm{Cu}$, while the denuded band has only $\mathrm{Cu}$.

The $\mathrm{Cu}$ matrix in this material would be expected to oxidize in the same way as pure $\mathrm{Cu}$, by outward diffusion of $\mathrm{Cu}^{+}$through the oxide scale as the rate limiting event [4]; and the precipitates probably react with oxygen that has diffused through the oxide scale to the substrate interface, in the manner proposed for $\mathrm{Cu}-\mathrm{Cr}$ and $\mathrm{Cu}-\mathrm{Nb}$ alloys [7-9]. Oxidation of the $\mathrm{Cr}_{2} \mathrm{Nb}$ precipitates best explains the enhanced oxidation resistance of $\mathrm{Cu}-8 \mathrm{Cr}-4 \mathrm{Nb}$ at intermediate temperatures, since these precipitates are the only point of difference from pure $\mathrm{Cu}$. That explanation relates to the consumption of extra oxygen to convert $\mathrm{Cr}_{2} \mathrm{Nb}$ to the mixed oxides. It is not possible to quantify this contribution to oxidation retardation without knowing all competing reactions so that oxygen consumption may be partitioned correctly. However, an analogy may be made to familiar systems. For instance, SiC and $\mathrm{Si}$ both have $\mathrm{SiO}_{2}$ as their only condensed oxidation product and both reactions have the 
same activation energy, $118 \mathrm{~kJ} / \mathrm{mol}$ [16]; yet the oxidation of $\mathrm{SiC}$ is $2-5$ times slower than that of $\mathrm{Si}$ and the difference is attributed to consumption of the extra oxygen needed to convert the carbon in $\mathrm{SiC}$ into $\mathrm{CO}$ [17]. While oxide scale thickening is controlled by inward diffusion of oxygen in Si oxidation and outward diffusion of copper in the present case, the principle is the same: secondary reactions retard the overall oxidation process by consuming extra oxygen.

Oxidation of $\mathrm{Cu}-8 \mathrm{Cr}-4 \mathrm{Nb}$ seems to differ somewhat from that of the $\mathrm{Cu}-\mathrm{Cr}$ and $\mathrm{Cu}-\mathrm{Nb}$ alloys studied by Chiang et al [7-9]. They suggested that the second phase (which was $\mathrm{Cr}$ or $\mathrm{Nb}$ ) oxidizes in-situ in the $\mathrm{Cu}$ matrix. In the present case, however, it is clear that $\mathrm{Cr}$ and $\mathrm{Nb}$ must cross the denuded band in Figs. 9 and 10 to get oxidized at the substrate$\mathrm{Cu}_{2} \mathrm{O}$ boundary. This suggests that the $\mathrm{Cr}_{2} \mathrm{Nb}$ precipitates dissociate into $\mathrm{Cr}$ and $\mathrm{Nb}$ ions, which diffuse through the $\mathrm{Cu}$ matrix in the denuded zone to react with oxygen beneath the primary scale. This raises a few possibilities regarding oxidation rate control in this alloy. Any of the steps involved in the secondary oxidation (viz: decomposition of $\mathrm{Cr}_{2} \mathrm{Nb}$, ionization of the atomic species, their diffusion through $\mathrm{Cu}$, or their reaction with oxygen at the $\mathrm{Cu}_{2} \mathrm{O}$-substrate boundary) could be the rate-limiting step in $\mathrm{Cu}-8 \mathrm{Cr}-4 \mathrm{Nb}$ oxidation - rather than the outward diffusion of $\mathrm{Cu}^{+}$through the $\mathrm{Cu}_{2} \mathrm{O} / \mathrm{CuO}$ scale.

The rate-determining process is, of course, the one with the highest activation energy. While the activation energy for $\mathrm{Cu}-8 \mathrm{Cr}-4 \mathrm{Nb}$ oxidation appears higher than that for $\mathrm{Cu}$ oxidation (Fig. 6), the evidence is not strong: due to the ambiguities noted earlier, one cannot be certain that the two activation energies in this figure $(98$ and $85 \mathrm{~kJ} / \mathrm{mol})$ are significantly different. For comparison, results obtained by Chiang and Grimmett for the same systems are re-plotted in Fig. 11 (by permission of the Electrochemical Society), with the axes converted to MKS units as in this paper). There is an excellent agreement between the present results and their $\mathrm{k}_{\mathrm{p}}$ values for $\mathrm{Cu}-8 \mathrm{Cr}-4 \mathrm{Nb}$ oxidation. (The data in Fig 6 for final-stage $\mathrm{Cu}-8 \mathrm{Cr}-4 \mathrm{Nb}$ oxidation should be left out of this comparison, since it applies to long oxidation times which were not explored by Chiang and Grimmett.) 
However, the results of Chiang and Grimmett fail to shed light on the key question of whether activation energies for $\mathrm{Cu}-8 \mathrm{Cr}-4 \mathrm{Nb}$ and $\mathrm{Cu}$ oxidation are significantly different in the intermediate-temperature regime of interest here $\left(\leq 700^{\circ} \mathrm{C}\right)$. The problem is that their plot for $\mathrm{Cu}$ (Fig. 11) is rendered as one straight line, while the temperature range of their study $\left(482-816^{\circ} \mathrm{C}\right)$ actually spans two different activation energy regimes for $\mathrm{Cu}$. Of their four data points for $\mathrm{Cu}$, the lowest belongs to the intermediate-temperature regime, while the other three belong to the high-temperature regime. The correct interpretation of $\mathrm{Cu}$ data is shown in Fig. 1 (which agrees with ref. 4). With only one $\mathrm{Cu}$ datum point in the intermediate temperature regime, the data of Chiang and Grimmett is too sparse for a proper regression to compare with the $\mathrm{Cu}$ plot in Fig. 6. Hence, Fig. 6 has to be taken at face value, and it indicates similar activation energies for $\mathrm{Cu}-8 \mathrm{Cr}-4 \mathrm{Nb}$ and $\mathrm{Cu}$ oxidation at intermediate temperatures but not at high temperatures. Above $\sim 700^{\circ} \mathrm{C} \mathrm{Cu}-8 \mathrm{Cr}-4 \mathrm{Nb}$ oxidation energy is somewhat lower for the initial oxidation stage but becomes higher in the terminal stage. The implication is that rate-controlling steps may be different for the two materials. Still, it is more likely that the accuracy achieved in this study is inadequate for a categorical conclusion on this point.

If oxidation of the second-phase precipitates is responsible for suppressing the aggregate oxidation kinetics in this alloy, it remains to be explained why this suppression seems to be ineffective at high temperatures. A likely explanation is that the same effect exists at higher temperatures but is overridden by other factors, such as diffusion rates that are now greatly increased for various reasons - including the prominence of a porous inner oxide zone.

\section{Conclusions}

The oxidation behavior of $\mathrm{Cu}-8 \mathrm{Cr}-4 \mathrm{Nb}$ in oxygen (and in air) differs significantly from that of $\mathrm{Cu}$ and NARloy- $\mathrm{Z}$ in many respects: (1) its rates are an order of magnitude slower in the interval 500 to $\sim 700^{\circ} \mathrm{C}$, but increase at higher temperatures to values comparable to that of $\mathrm{Cu}$; (2) the increase of $\mathrm{Cu}-8 \mathrm{Cr}-4 \mathrm{Nb}$ oxidation rates at higher temperatures is accompanied by bifurcation into two kinetic regimes: a fast rate (several times faster that that of $\mathrm{Cu}$ ) for the first $\sim 10$ hours of oxidation, and a slower rate (equal to that of $\mathrm{Cu}$ ) in 
the final stage of oxidation; (3) correspondingly, the inner (early) oxide growth is highly porous and hence poorly protective, while the outer (final) oxide is dense and blocky; (4) a layer of mixed $\mathrm{Cr}$ and $\mathrm{Nb}$ oxides separates the main scale, which corresponds to the oxides of copper, from the $\mathrm{Cu}-8 \mathrm{Cr}-4 \mathrm{Nb}$ substrate - and formation of this "secondary" oxide film is thought to be responsible for the reduced oxidation rates of $\mathrm{Cu}-8 \mathrm{Cr}-4 \mathrm{Nb}$ below $\sim 700^{\circ} \mathrm{C}$.

\section{Acknowledgment}

GRCop-84 (Cu-8Cr-4Nb) and NARloy-Z samples were provided by D.L. Ellis of Case Western Reserve University, and the TGA exposures were performed by D.L. Humphrey of QSS, Inc. Their assistance is highly appreciated. The author also wishes to thank J.L. Smialek for useful discussions of this manuscript.

\section{References}

1. D.L. Ellis, G.M. Michal, and N.W. Orth, Scripta Met vol 24 (1990) 885

2. D.B. Morgan, T. Nguyentat, J.E. Franklin, and A.C. Kobayashi, "Investigation of Copper Alloy Combustion Chamber Degradation by Blanching", Proceedings of the Advanced Earth-to-Orbit Propulsion Technology Conference, NASA Marshall Space Flight Center, Huntsville, AL, May 13-15 1986.

3. A. Ronnquist and H. Fischmeister, J. Inst. of Metals, vol 89 (1960-61) 65-76

4. J. -H. Park and K. Natesan, Oxidation of Metals, vol 39 \#s5/6 (1993) 411-35

5. S.K. Bose, S.K. Mitra, and S.K. Roy, "Oxidation of Copper Under StaticCharge Supply", Trans. Indian Inst. Metals, vol. 50 \#1 (1997) 85-96

6. S.K. Roy, S.K. Mitra, and S.K. Bose, "Influence of an Externally Applied Static Charge on the Oxidation Kinetics of Copper", Oxidation of Metals, vol 49, \#s 3/4 (1998)

7. K.T. Chiang, P.D. Krotz, and J.L. Yuen, Surface and Coatings Tech., 76-77 (1995) 14-19

8. K.T. Chiang and J.P. Ampaya, Surface and Coatings Tech., 78 (1996) 243-7

9. K.T. Chiang, K.J. Kallenborn, J.L. Yuen, and N.E. Paton, Mater. Sci. \& Eng., A156 (1992) 85-90 
10. K.T. Chiang and D.L. Grimmett, Electrochemical Society Proc., vol. 98-9 (1998) 489-99

11. R.J. Hanrahan, et al., "High Temperature Oxidation of Be-Modified Intermetallic Compounds of the Nb-Cr System", High Temperature Corrosion \& Materials Chemistry III, ECS Proceedings vol. 2001-12, ed. E. Opila and M. McNallan, The Electrochem. Soc., Inc. (2001), 77-83

12. L.U.J.T. Ogbuji, "Sub-parabolic Oxidation Behavior of Silicon Carbide”, J. Electrochem. Soc., vol. 145, No. 8 (1998) 2877-82

13. C.E. Lowell, et al., "COSP: A Computer Model of Cuclic Oxidation”, Oxidation of Metals, vol. 36, Nos. 1-2 (1991), 81-112

14. C.S. Tedman, "The Effect of Oxide Volatilization on the Oxidation of $\mathrm{Cr}$ and $\mathrm{Fe}-\mathrm{Cr}$ Alloys", J. Electrochem. Soc., vol. 113 No. 8 (1966) 766-8

15. E.J. Opila and R.E. Hann, "Paralinear Oxidation of CVD SiC in Water Vapor", J. Am. Ceram. Soc., 80 [1] (1997) 197-205

16. L.U.J.T. Ogbuji and E. Opila, "A Comparison of the Oxidation Kinetics of SiC and $\mathrm{Si}_{3} \mathrm{~N}_{4}$ ", J. Electrochem. Soc., vol. 142 No. 3 (1995) 925

17. L. Filipuzzi and R. Naslain, "Oxidation Kinetics of $\mathrm{SiC}$ Deposited From $\mathrm{CH}_{3} \mathrm{SiCl}_{3}$ Under CVI Conditions”, J. Mater. Sci., 27 (1992) 3330 


\section{Table Captions}

Table 1, Durations and parabolic rate constants for the two kinetic regimes observed in the oxidation of $\mathrm{Cu}-8 \mathrm{Cr}-4 \mathrm{Nb}$ at high temperatures

Table 2, Oxides detected by $\mathrm{XRD}$ on $\mathrm{Cu}-8 \mathrm{Cr}-4 \mathrm{Nb}$ after oxidation at intermediate and high temperatures; the secondary $(\mathrm{Cr}$ and $\mathrm{Nb})$ oxides were detected only after removal of the $\mathrm{Cu}_{2} \mathrm{O} / \mathrm{CuO}$ overburden

\section{Figure Captions}

Fig. 1 Arrhenius plot of the oxidation data for pure $\mathrm{Cu}$ at intermediate and high temperatures, showing activation energies in the two regimes

Fig. 2 Kinetic plots for NARloy- $\mathrm{Z}$ and $\mathrm{Cu}$ (the two benchmark materials for this study); their kinetics are effectively the same at intermediate and high temperatures

Fig. 3 Oxidation kinetic of $\mathrm{Cu}-8 \mathrm{Cr}-4 \mathrm{Nb}$ at representative temperatures: The kinetics are essentially parabolic, but split into two different parabolic regimes (I and II) at high temperatures.

Fig. 4 Arrhenius plot for $\mathrm{Cu}-8 \mathrm{Cr}-4 \mathrm{Nb}$ oxidation in air and oxygen, at all temperatures investigated, showing that the behavior is the same in both ambients

Fig. 5 Arrhenius plot of $\mathrm{Cu}-8 \mathrm{Cr}-4 \mathrm{Nb}$, NARloy-Z, and $\mathrm{Cu}$ oxidation data: all three have comparable oxidation rates at high temperatures, but $\mathrm{Cu}-8 \mathrm{Cr}-4 \mathrm{Cr}$ oxidizes at considerably slower rates than the two materials below $\left(\sim 700^{\circ} \mathrm{C}\right)$ 
Fig. 6 Arrhenius plot showing the complex kinetics of $\mathrm{Cu}-8 \mathrm{Cr}-4 \mathrm{Nb}$ oxidation (compared to $\mathrm{Cu}$ ): slower rates at intermediate temperatures and a split at high temperatures into a fast branch (initial oxidation) branch and a slow branch (terminal kinetics)

Fig. 7 Plot showing the split of $\mathrm{Cu}-8 \mathrm{Cr}-4 \mathrm{Nb}$ oxidation kinetics into parabolic regimes I and II at $800^{\circ} \mathrm{C}$, and SEM images from corresponding depths in the oxide. Images I and II have identical magnification; the inset (below I) is $10 \mathrm{X}$ higher.

Fig. 8 Comparison of oxides scales grown at $800^{\circ} \mathrm{C}$ on (a) $\mathrm{Cu}-8 \mathrm{Cr}-4 \mathrm{Nb}$, (b) NARloy-Z, and (c) $\mathrm{Cu}$; block arrows indicate the oxide/metal boundaries; the NARloy- $Z$ oxide is dense and uniform, the $\mathrm{Cu}$ oxide is uniform, except for large pores, while the $\mathrm{Cu}-8 \mathrm{Cr}-4 \mathrm{Nb}$ oxide has two zones exhibiting different degrees of consolidation

Fig. 9 (a) SEM micrograph of $\mathrm{Cu}-8 \mathrm{Cr}-4 \mathrm{Nb}$ after removal of the $\mathrm{Cu}_{2} \mathrm{O} / \mathrm{CuO}$ scale grown at $800^{\circ} \mathrm{C}$; (b) EDS scan across the secondary $(\mathrm{Cr}+\mathrm{Nb})$ oxides to the substrate

Fig. 10 Enlarged view of a portion of the SEM image in Fig. 9, accompanied by EDS maps showing the distribution of $\mathrm{Cu}, \mathrm{Cr}$, and $\mathrm{Nb}$

Fig. 11 Reproduction of Fig. 4, ref. 10 (with permission of the Electrochemical Society), for oxidation of $\mathrm{Cu}-8 \mathrm{Cr}-4 \mathrm{Nb}$ and $\mathrm{Cu}$; since only one activation energy is indicated in this plot for $\mathrm{Cu}$ oxidation in the whole interval, it cannot be directly compared to the oxidation mechanisms suggested in the present work 


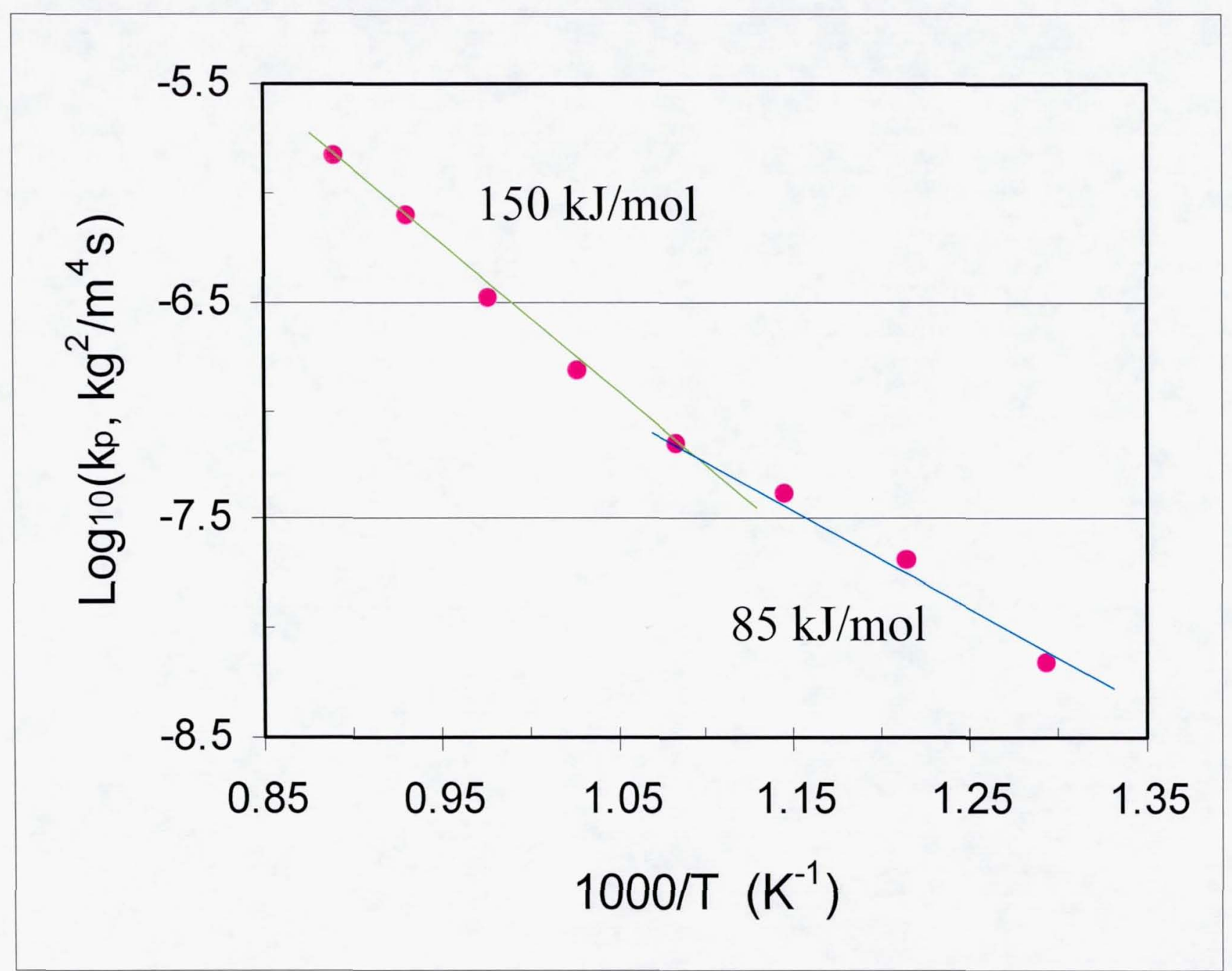


$\underline{\text { Oxidation behavior of NARloy \& } \mathrm{Cu} \text { are Same at Hi \& Lo Temps }}$

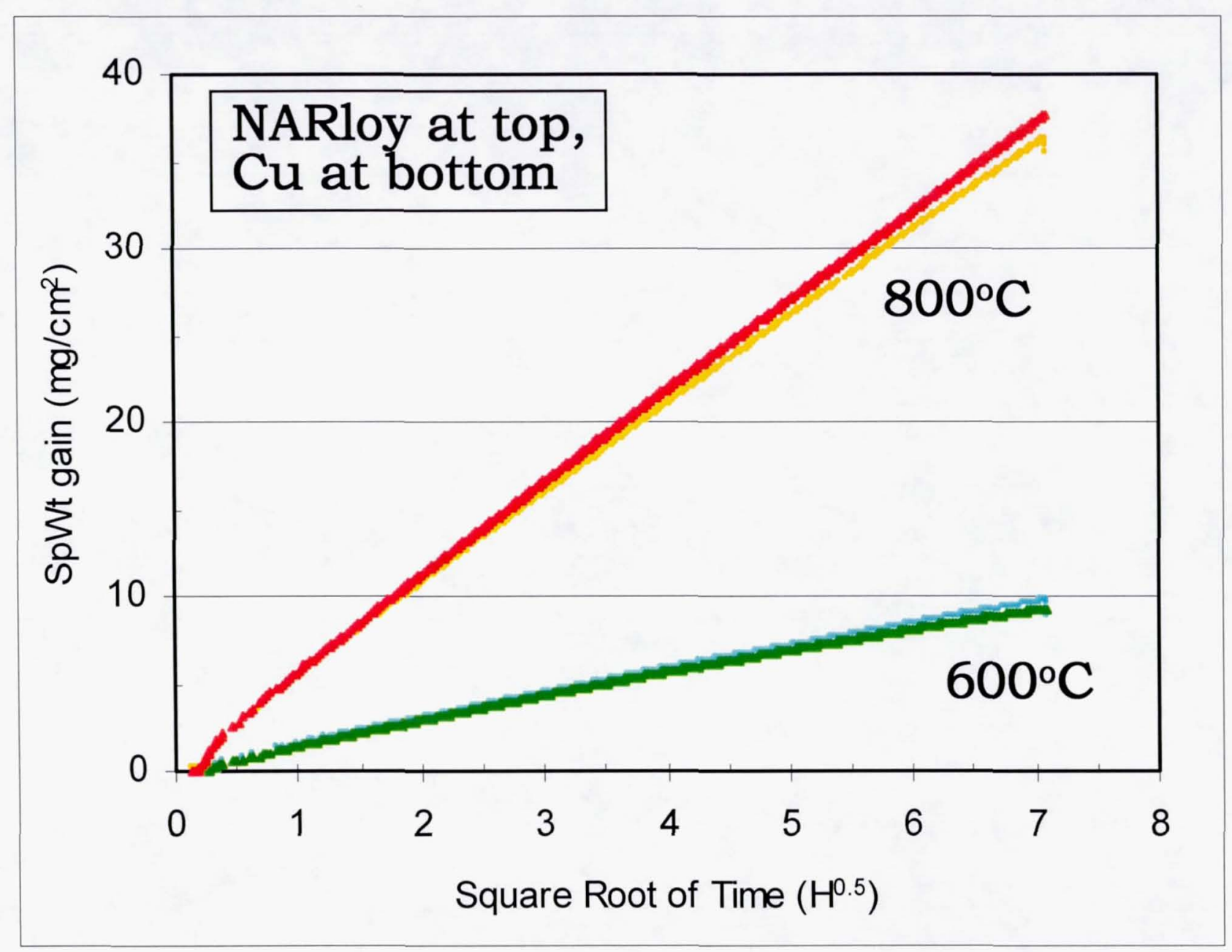




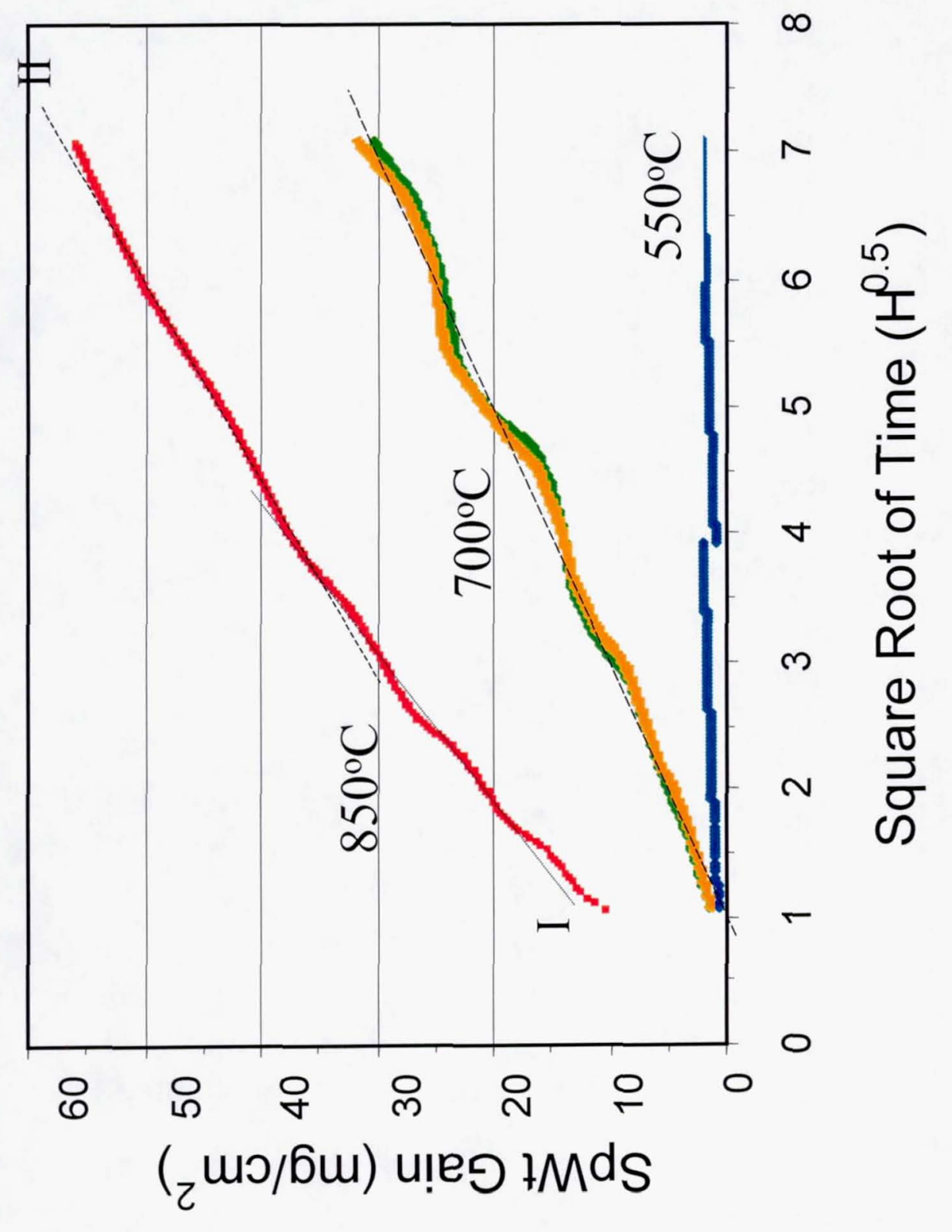




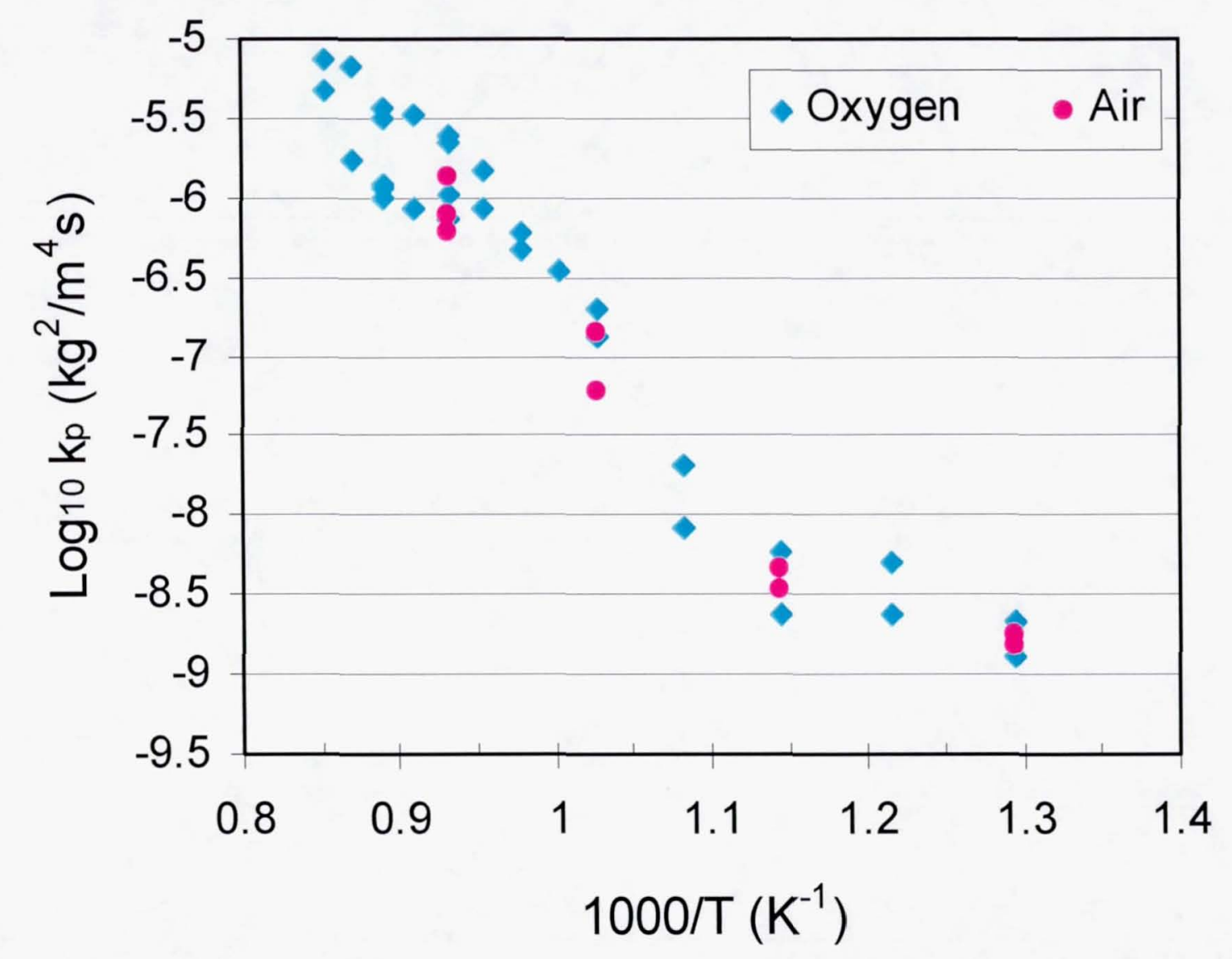




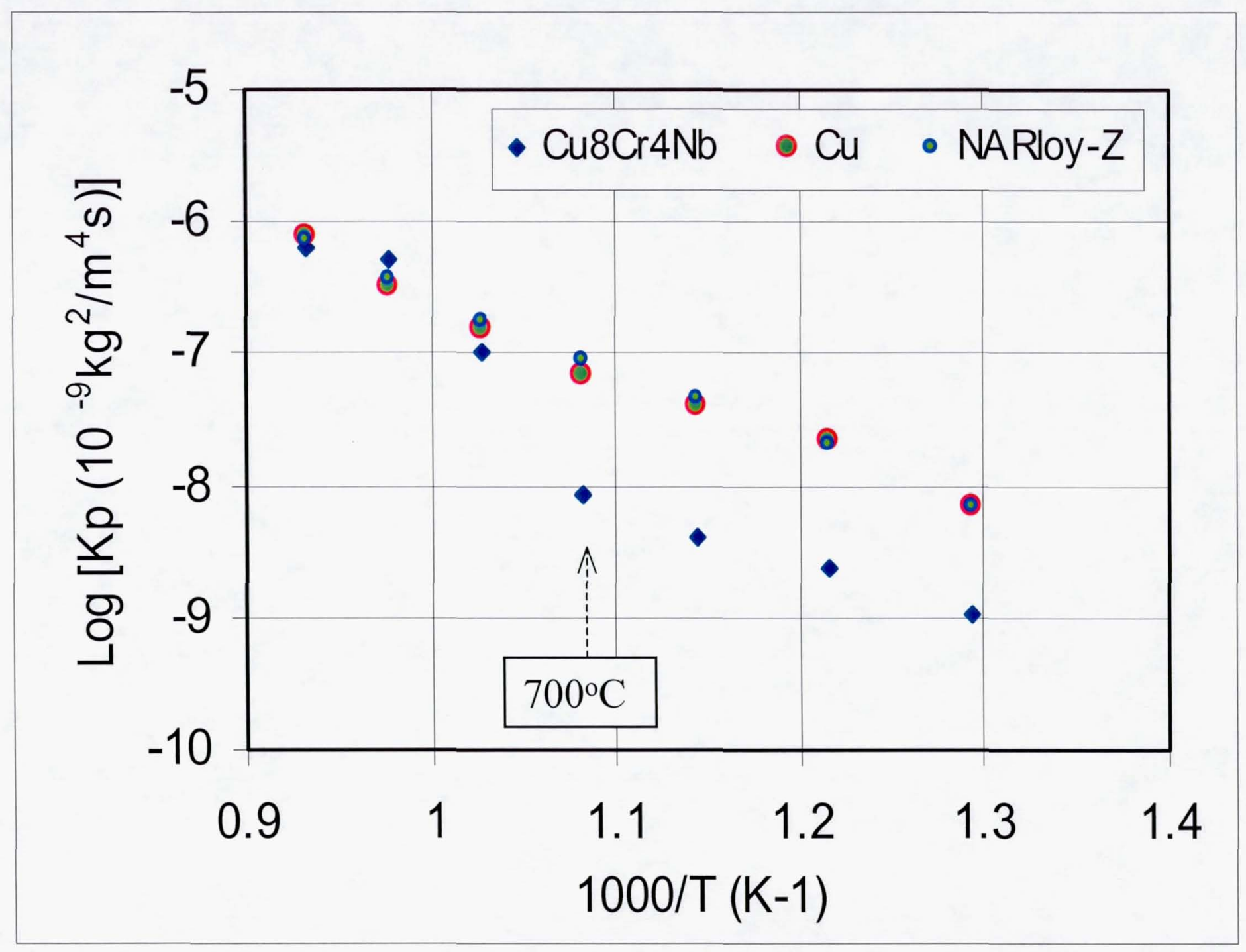




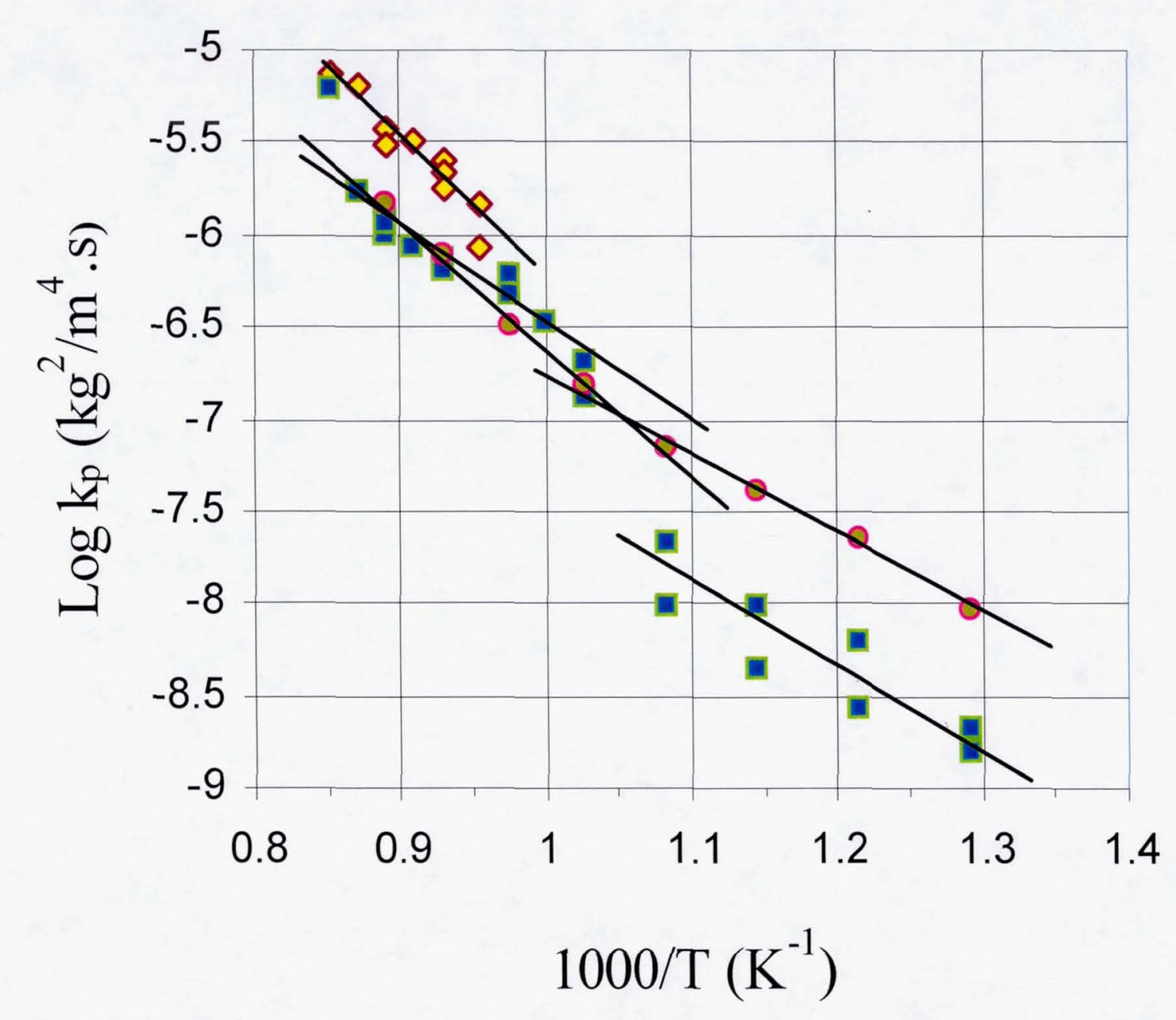

$\diamond$ GRCop-84(initial) $\quad$ GRCop-84(terminal) • Copper 

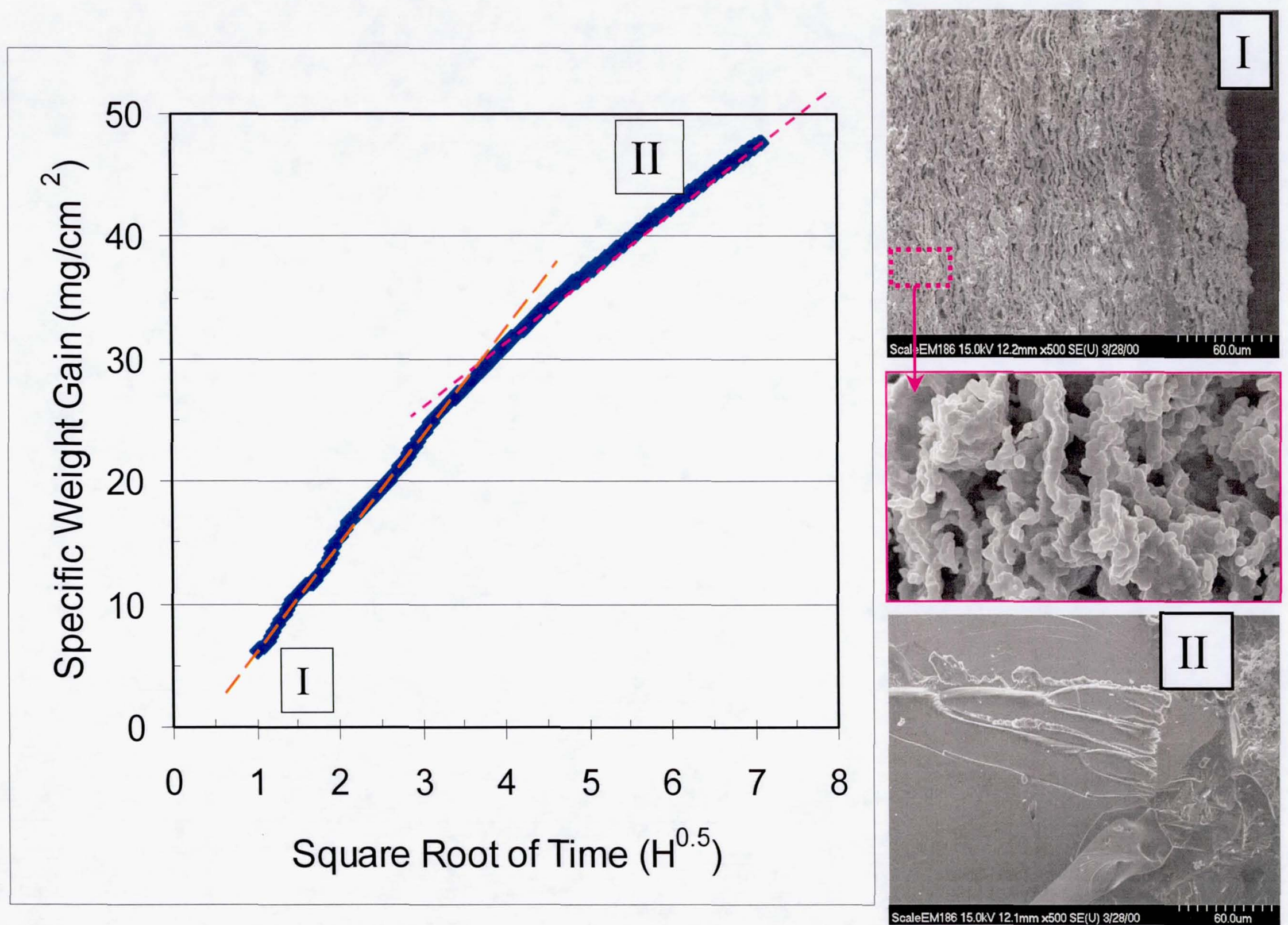


\begin{tabular}{|c|c|c|c|c|c|}
\hline Temp. $\left({ }^{\circ} \mathrm{C}\right)$ & $\begin{array}{r}\text { Regime I (H) } \\
(\text { av) }\end{array}$ & $\begin{array}{r}\text { Regime II (H) } \\
\text { (av) }\end{array}$ & $\begin{array}{c}\mathrm{K}_{\mathrm{I}}\left(10^{-6} \mathrm{~kg}^{2} / \mathrm{m}^{4} \mathrm{~s}\right) \\
\text { (av) }\end{array}$ & $\begin{array}{c}\mathrm{K}_{\mathrm{II}}\left(10^{-6} \mathrm{~kg}^{2} / \mathrm{m}^{4} \mathrm{~s}\right) \\
(\mathbf{a v})\end{array}$ & $\begin{array}{r}\mathrm{K}_{\mathrm{I}} / \mathrm{K}_{\mathrm{II}} \\
(\text { av) }\end{array}$ \\
\hline 800 & (10) & $\begin{array}{l}25 \\
30 \\
28 \\
35 \\
0(15-\mathrm{H} \text { run }) \\
\quad(\mathbf{3 0})\end{array}$ & $\begin{array}{l}1.97 \\
2.16 \\
1.78 \\
1.96 \\
1.89\end{array}$ & $\begin{array}{l}0.630 \\
0.748 \\
0.625 \\
0.868\end{array}$ & (2.83) \\
\hline 825 & 10 & 30 & 2.564 & 0.865 & 2.96 \\
\hline 850 & (9) & (28) & (3.13) & (1.10) & \begin{tabular}{|lr}
2.88 & \\
2.70 & \\
2.61 & \\
& $(\mathbf{2 . 7 3 )}$ \\
\end{tabular} \\
\hline 875 & 4 & 43 & 6.55 & 4.86 & 1.35 \\
\hline 900 & 2 & 45 & 7.24 & 5.91 & 1.23 \\
\hline
\end{tabular}



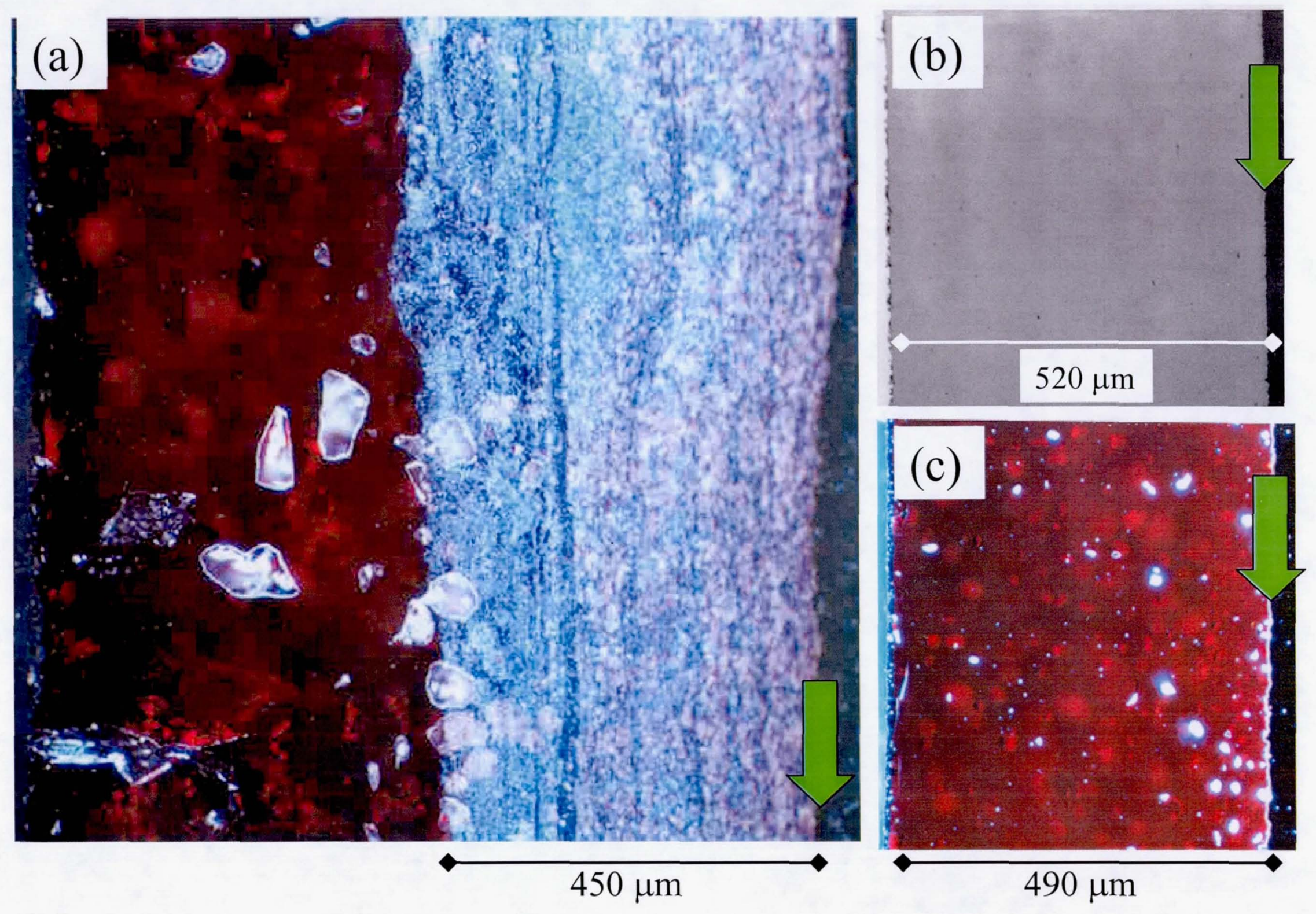


\begin{tabular}{|c|c|c|c|c|}
\hline \multirow{2}{*}{$\begin{array}{l}\text { Temp } \\
\left({ }^{\circ} \mathrm{C}\right)\end{array}$} & \multirow{2}{*}{$\begin{array}{l}\text { Whole } \\
\text { Sample }\end{array}$} & \multicolumn{3}{|c|}{ Oxide Scale Removed From Substrate } \\
\hline & & Scale, from Top & Scale, from Bottom & Substrate, from Top \\
\hline 650 & & $\begin{array}{l}\mathrm{CuO} \\
\mathrm{Cu}_{2} \mathrm{O}\end{array}$ & $\begin{array}{ll}\mathrm{Cu}_{2} \mathrm{O} & \\
\mathrm{CuNb}_{2} \mathrm{O}_{6} & \text { (probable) } \\
\mathrm{CuCrO}_{2} & \text { (possible) } \\
\mathrm{CrO}_{2} & \text { (possible) }\end{array}$ & \\
\hline 750 & & $\begin{array}{l}\mathrm{CuO} \\
\mathrm{Cu}_{2} \mathrm{O}\end{array}$ & Wafer sample, complet & y converted to oxide \\
\hline 800 & $\begin{array}{l}\mathrm{CuO} \\
\mathrm{Cu}_{2} \mathrm{O}\end{array}$ & & $\begin{array}{l}\mathrm{CrNbO}_{4} \\
\mathrm{CuCrO}_{4} \\
\mathrm{CuNb}_{2} \mathrm{O}_{6}\end{array}$ & $\begin{array}{l}\mathrm{CrNbO}_{4} \\
\mathrm{CuCrO}_{2} \\
\mathrm{CuNb}_{2} \mathrm{O}_{6} \\
\mathrm{Cr}_{2} \mathrm{O}_{3} \text { (possible) } \\
\mathrm{Cu}\end{array}$ \\
\hline 850 & & $\begin{array}{l}\mathrm{CuO} \\
\mathrm{Cu}_{2} \mathrm{O} \text { (minor) }\end{array}$ & $\begin{array}{l}\mathrm{CrNbO}_{4} \\
\mathrm{CuCrO}_{4} \\
\mathrm{CuNb}_{2} \mathrm{O}_{6}\end{array}$ & $\begin{array}{l}\mathrm{CrNbO}_{4} \\
\mathrm{CuCrO}_{2} \\
\mathrm{Cr}_{2} \mathrm{O}_{3} \quad \text { (probable) } \\
\mathrm{Cu}\end{array}$ \\
\hline 875 & $\begin{array}{l}\mathrm{CuO} \\
\mathrm{Cu}_{2} \mathrm{O}\end{array}$ & & $\begin{array}{l}\mathrm{CrNbO}_{4} \\
\text { Unidentified } \\
\text { Spinel oxide }\left(\mathrm{a}_{0}=8.05\right)\end{array}$ & $\begin{array}{l}\mathrm{CrNbO}_{4} \\
\text { Unidentified spinel } \\
\mathrm{Cr}_{2} \mathrm{O}_{3} \quad \text { (probable) } \\
\mathrm{Cu}\end{array}$ \\
\hline 900 & $\begin{array}{l}\mathrm{CuO} \\
\mathrm{Cu}_{2} \mathrm{O}\end{array}$ & & $\begin{array}{ll}\mathrm{Cu}_{2} \mathrm{O} & \text { (probable) } \\
\mathrm{CuCrO}_{2} & \text { (probable) }\end{array}$ & $\begin{array}{l}\mathrm{CrNbO}_{4} \\
\mathrm{Cr}_{2} \mathrm{O}_{3} \quad \text { (probable) } \\
\mathrm{Cu}\end{array}$ \\
\hline
\end{tabular}



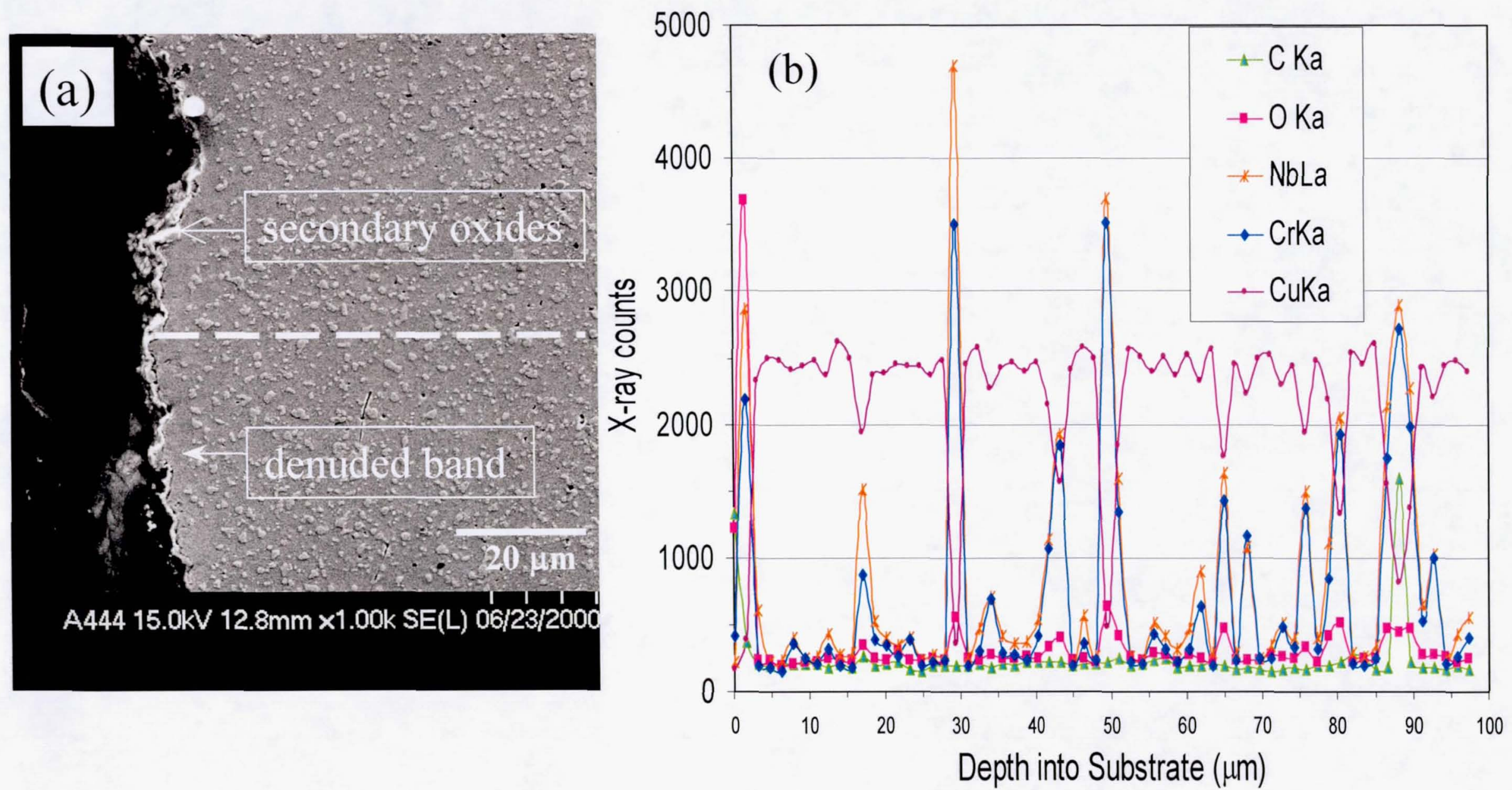

Fig. 9 


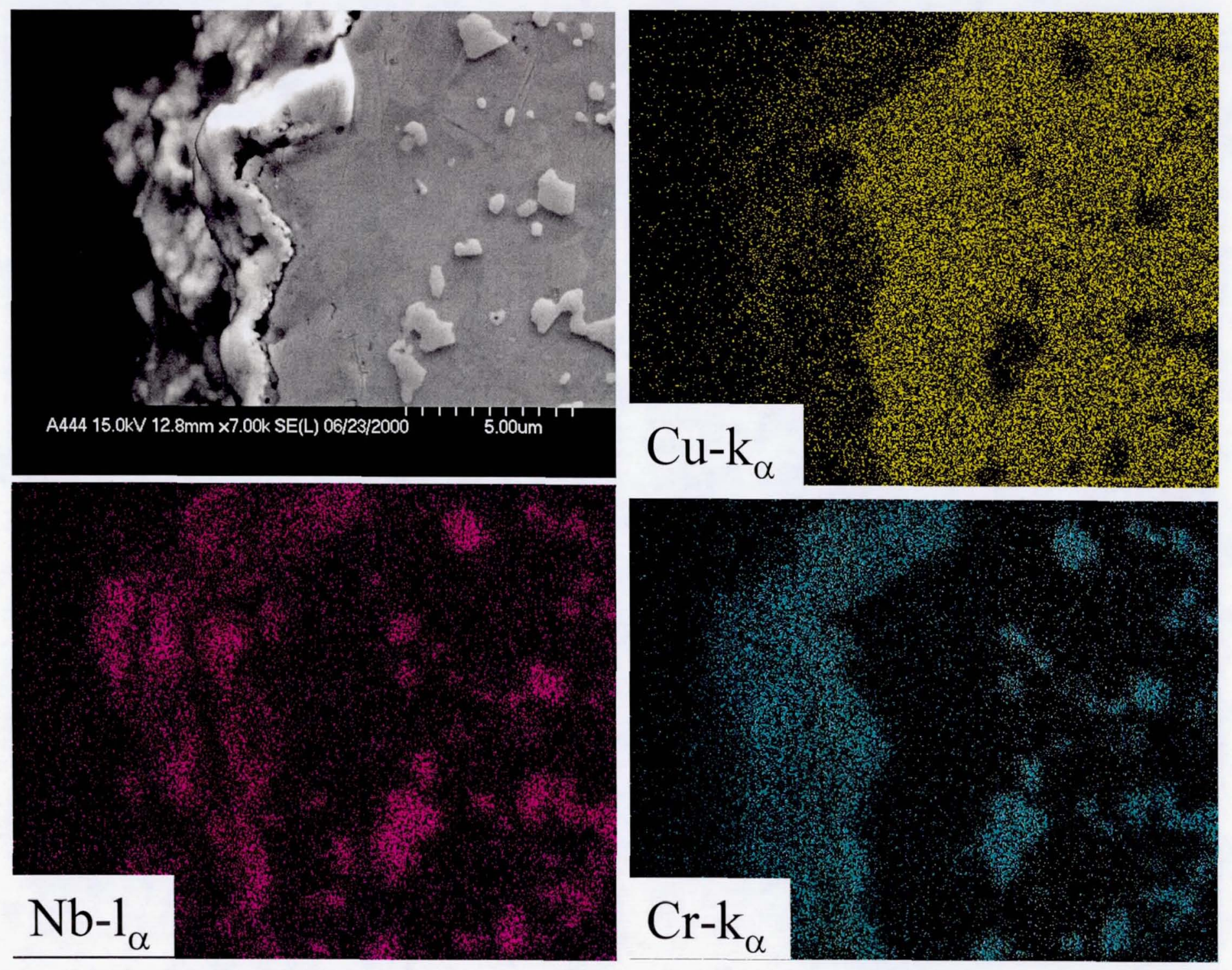




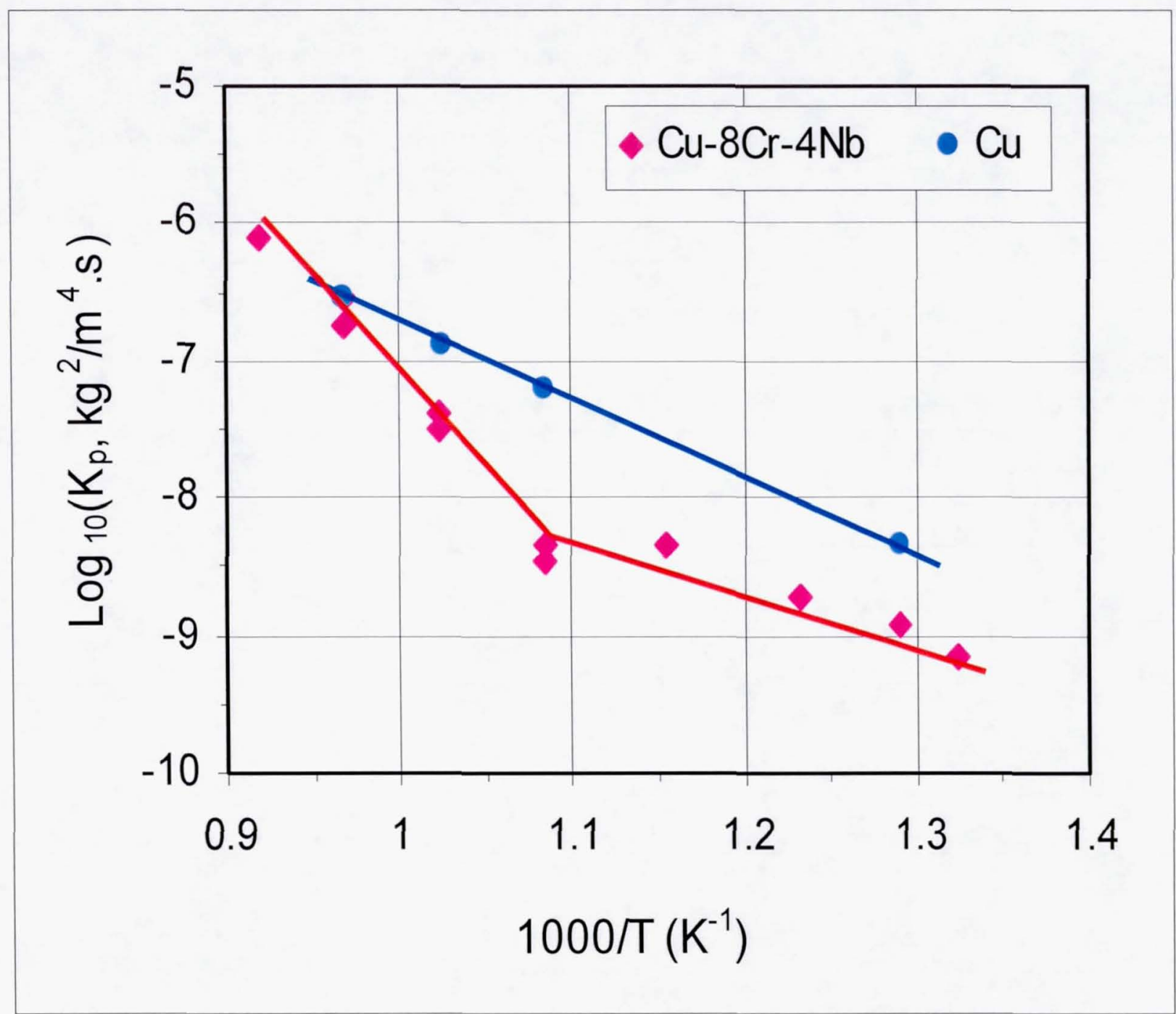

- 